\title{
AN EVALUATION OF LEGAL POLICY RELATED TO THE IMPLEMENTATION OF THE SIMULTANEOUS LOCAL ELECTION (A FIRST INDONESIA PERIOD OF THE SIMULTANEOUS LOCAL ELECTION)
}

\author{
Agus Riwanto \\ Faculty of Law, Sebelas Maret University \\ Email:agusriewanto@yahoo.com
}

\begin{abstract}
Indonesia legal policy of the simultaneous local election to appoint a district head had been amended by Law Number 8 of 2015 concerning the local election (governors, regents and mayors) from the regular models to the simultaneous models. Simultaneous local election will be implemented in periods, namely a first period in 2015, a second period in 2017, a third and fourth period will be approximately held from 2018 to the 2021, and a national simultaneous local elections will be held in 2027. The simultaneous local election is aimed to make the efficiency and effectiveness of the budget, time and labor organizer; to eliminate boredom voters; to increase public control. Law Number 8 of 2015 had been reviewed judicially thirdty first times. The Constitutional Court also issued a surpprised decision which change a political constellation of Indonesia. The political aspect of simultaneous local election in 2015 need to be fixed through the revision of Law Number 8 of 2015 in order to create the system of the simultaneous elections fairly and democratically for the implementation of the next period: the required transfer of election financing from the budget to the state budget; the need to create a model for the preliminary election; restrictions on candidacy requirements; a dispute settlement of the simultaneous local election to the supreme court; a time restrictions on the election administration disputes lawsuit in the Administrative Court; and we need to build a model of election law enforcement system integration.
\end{abstract}

Key Word: legal policy evaluation, simultaneous local election

\section{A. INTRODUCTION}

Election of locally political leaders was held on December 9, 2015 by simultanous election in the area of 264 from 269 planned area (consists of 8 provinces, 222 regencies and 34 cities). Simultaneous election systems is the first history of elections in Indonesia. The implementation of simultaneous election systems is a mandate of the Law Number 8 of 2015 concerning a revision of Law Number 1 of 2015 regarding the Election of Governors, Regents and Mayor, as well as Law Number 2 of 2015 on Local Government which was ratified by the House of Representatives on 16 February 2015 from 2014 to 2019 period and the local election results in the era of the new government of President Ir. Joko Widodo-Jusuf Kalla. (Kompas, 17 February 2015: 1). 
The simultaneous election systems ruled by the first rules is not really simultan, as in the theory of simultaneous elections, which carried out nationally at the same time, well, date, month and day are the same. (August Mellaz, 2007: 2).

Even though a simultaneous system exercised differently by many countries democratically. There is also the tradition of simultaneous elections supposed to carry out a national elections to choose a president and legislators at the same time and for local elections to elect a regional head and parliamentary elections to choose members of parliament at the same time simultaneously. (David Samuels, 2000: 1-20). The simultaneous election systems is carried out gradually and not exercised at the same time for 542 autonomous regions which consists of: 34 provinces; 415 districts and 93 cities. The nationally simultaneous election systems aimed to all new autonomous region will be implemented in the beginning of 2027. One reason for the life of the head area in Indonesia is not the same, so that the General Election can not be implemented in the same time and needed a model to simultaneously interpret this to be gradual.

The presence of Law Number 8 Year 2015 placed simultaneous models adopted by a mechanisms of direct participation by the people (direct election) is not necessarily, but through the process for a long time. For the 2009-2014 period the previous parliament and government (SBY-Boedioyono) wishes Election will be not held directly, but elected by parliament.

The cornerstone of the 1945 constitution did not provide a reason why, that the head of the region should be directly elected. Article 18 Paragraph (5) of the 1945 Constitution only put the head of the region "elected democratically". Democratic meaning can be adapted to the context of the political interests of the legislator. A constitutional interpretation that opens the opportunity to tamper with the system of direct and indirect Election. (Budiman Tanuredjo, 2012: 210-243). In this case the period of 2009-2014 DPR and the government of SBY interpret this democracy system elected by the Parliament and not by the people.

The main reason of the election model changes directly to a representative of the parliament's version of the bill include: First, a wasteful and a expensive budget spent by local governments through the budget for financing the implementation of the general election. Second, the high cost of informally political incurred by a prospectively head region in the election process, especially for the cost of candidacy in political parties, money socialization, campaign and political consolidation of the political constituencies. Third, the magnitude of the financial costs will be incurred by the local government 
through budget funds, which reached a total of $4-10 \%$ of the budget for each province and district/city. Fourth, the magnitude of the political conflicts and violence between supporters of candidates in the general election. Fifth, a culture of political corruption that led the head of the region due to the high costs incurred when the general election. Sixth, the strengthening of political money (money politics), ranging from the bureaucracy, politicians and the public. (Mahfud MD, 2012: 3-18).

The other hand, Election elected by parliament has sparked protests from some quarters because it will be negative implications. This election model chosen by parliament will have implications for the law on missing and the death of political participation of the people in the process of selecting the head of the local level as the destruction of the role of local government control of the course, because it ensures all policies in the area will only be discussed in private between parliament and the head of the region. Though a number of political theory include Larry Daimond (2010), for example, indicated that political participation is a hallmark of the broadest masses of the most essential of the success of the practice of democracy in the post-new order Indonesia. (Larry Daimond, 2010: 21-52).

The locally political leaders election is not immediately evident will close political participation of the people in selecting and determining the political head in that area. When participation systematically closed, meaning that future growth is democratic oligarchy or democracy of elites. Some theorists like O'Neil (2005) says: "all politics is local 's", the real growth of democracy in a country of good and bad depend on local democracy, if democracy flourishes and goes well in the area, will certainly contribute to the growth of accumulation blossoms democracy at the center of power. (Djohermansyah Djohan, 2009: 1).

The movement of the model election from direct to indirect system is a deterioration of Indonesian democracy. This reason can be accepted by the political elite and political elite finally retaining election models directly. Simultaneous election system, the system adopted in 2015 and has not been quite perfectly and create a better system for the implementation of the general election 2017. At least it can be proven from the latest data presented the Constitutional Court throughout in the last 2015 years. Constituonal court has received 140 cases of judicial review of the public and the Law 8 Year 2015 regarding the election of governors, regents and mayors 31 times, it is the largest claim in the history of the general election in Indonesia. (Kompas, 2015: 2).

B. 


\section{B. PROBLEM STATEMENT}

At this point, it requires a critical evaluation of the implementation of Law Number 8 of 2015 on the General Election of Governors, Regents and Mayors (simultaneous election system) The first stage in 2015. In the future, this matter is expected to be able to create a model of the simultaneous election system democratically and equitably for the implementation of the next period of simultaneous election system.

\section{C.RESEARCH METHODS}

In this approach, the secondary data such as documents or literature is thoroughly researched to collect information on laws and regulation, written data, books, seminar results, research output, and other references, and data and information through websites related to the problem discussed in this research.

The secondary data collected to be analysed consists of:

a. Legal primary sources such as law and regulation, and legal documents related to election;

b. A legal secondary source such as books, research output, papers, and articles from the legal experts.

c. A legal tertiary source such as legal dictionary, encyclopedia, and other information related to the registration of voters in implementing the people sovereignty.

The secondary data then analyzed qualitatively to be presented for the making the final conclusion. The conclusion would be made using the deductive technique, in which one finding the lead to generalization of a problem.

\section{DISCUSSION}

\section{Legal Policy Function Simultaneous Election System}

The selection of legal policy or the official policy on the election law in which will be applied to turn the older election law in the context of national goals is to shift the regular election model in the form of time as adopted Law Number 8 of 2015 (Mahfud MD (2010: 1). This is a legal framework which is prepared systemically as an effort to manipulate the electoral system to the national interest and outlined a political objective addressed by a country. (Alan Wall and Mohamed Salih, 2007: 6).

There is also the long-term interests of the intended politically choices election law regarding a simultaneous system is: First, for the efficiency and effectiveness of the budget, within simultaneous models will be able to save costs which can be incurred in the General Election. Second, saving time and labor organizers. Third, eliminate boredom 
voters. Fourth, increasing public control. Fifth, the central and local governments to produce the same (concruent).

Sixth, the presence of a coattail effect, (Matt Golder, 2006, 34-38), which give rise to a political action to another action (Effect of follow-up). It is associated with psychological factors of voters in determining the choice in the election, in which voters have a tendency for a leader of a political party popularly to be nominated for the office of The Executive (president, governors, mayors, regents) give rise to the appeal of voters to other candidates of political parties in the general election.

Simultaneous election system will also reduce a flurry of political parties in the internal conflict and encourage a political parties to establish a relationship with constituents, reproduce opportunity cadres competing political parties, the government formed a constructive and create a five-year political agenda is clear. (Siti Zuhro, 2015: 367).

Any electoral system can be viewed from four sides, ie: systems, management, law enforcement and actor. There is no definition of an electoral system is interconnected technically instrument election in converting votes into seats for the legislative elections and convert sound into a tool in the election victory of the executive (president, governors, regents and mayors). Election system at least that need attention are related to the schedule, terms of membership, nomination methods, and formulas selected candidates. (Didik Supriyanto, 2012: 211).

Simultaneous election system which began in 2015 is intended to be able to create a continuous arrangement of the electoral system with the national electoral simultaneous system. At least the court has made a decision that the upcoming 2019 elections can be held simultaneous nationwide for the elections for members of DPR, DPD and DPRD incorporated in the implementation and the same day as the election of president and vice president.

Therefore, a simultaneous election system expected to become embryos and experimentation towards national elections simultaneously. This concept is also intended future will give a model of the simultaneous election system nationally which will take place in the coming year 2027 with simultaneous election system gradually. Legal policy of the simultaneous election system in the Indonesia election law will be implemented in four waves, each of which is based on the end of the tenure which can be broken out as follows: 
a. The first batch was held simultaneously on December 2015 to elect the head of local government; (Article 157 paragraph (2) Law Number 8 of 2015 on the Election of Governors, Regents And Mayors).

b. The second batch was held simultaneously on February 2017 for the head of district who their retire on July to December 2016 and year 2017; (Article 201 paragraph (2) Law Number 8 of 2015 on the Election of Governors, Regents and Mayors).

c. The third batch was carried out simultaneously on June 2018 to the Head of district which their retire in 2018 and year 2019; (Article 201 Paragraph (3) Law Number 8 of 2015 on the Election of Governors, Regents And Mayors).

d. Simultaneously electoral system will be held nationally in 2027 (Article 201 paragraph (7) Law Number 8 of 2015 on the Election of Governors, Regents And Mayors).

In the future, Indonesia will only have two elections in five years, the national elections to choose the DPR, DPD, DPRD and appoint the president and vice president and local elections to elect regional heads (governors, regents and mayors).

\section{Evaluation of the Implementation of the Simultaneous Election System in 2015}

The simultaneous election system on December 9, 2015 can not take place as planned and it should take place in the 269 area, but in reality can only take place in the 264 area, there are five areas which failed to exercise, namely Central Kalimantan Province, Regency of Fak-Fak, Simalungun, Pematang Siantar and Manado city. Because of a dispute beyond the nomination submitted by the candidates to the State Administrative Court (Administrative Court). As a result, the five stages of election in this area can not be carried out completely in 2015, had to be postponed implementation in 2016.

The simultaneous election system of 2015 accompanied by the new reality which is not accommodated into Law Number 8 of 2015, because there are three areas that only have a single regional head candidates, which is in the district of Tasikmalaya, Kab. Blitar and North Central Timor, despite a couple of candidates extended registration period. As a result of this single candidate into national attention and most of those election delayed the implementation of the general election in the next year. But this reason is rejected, because the Constitutional Court made a controversial decision authorizing their single candidate in the simultaneous election system.

The Constitutional Court considered a public concern for making various decisions which is unique and unusual in the electoral system in Indonesia. At least Law Number 8 /of 2015 which has been sued 31 times by the parties, because they are not able to create fairness 
in the competition. The fairness of the competition is one of the main characteristics of the design of the electoral system of democracy. When the competition can not be presented fairly and objectively, then the actual design of the electoral system was designed in the Act has created discrimination from birth. (John Rawls: 1971: 11).

A number of controversial Constitutional Court decision noteworthy public and could affect the national political constellation throughout the election of 2015 that there were at least five (5). First, the decision of the Constitutional Court which sets civil servants, military/police and members of the DPR, DPD and DPRD obliged to resign from his post status since run for the prospective head region. Secondly, the Constitutional Court's decision to allow former inmates to run for the prospective district head. Third, the decision of the Constitutional Court which refused their relatives restriction incumbent in this election. This means that the Court authorize their political dynasty. Fourth, the decision of the Constitutional Court which dismissed the suit Dispute Election Results which do not meet the threshold requirement, the margin between the winner and the loser is approximatelly 0.5 percent-2 percent as stipulated in Article 158 Paragraph (1), (2) and (3) of Law Number 8 of 2015. Fifth, the Constitutional Court's decision that allows for a single candidate to continue to implement the General Election. (Djohermansyah Djohan, 2016: 4).

The simultaneous election system of 2015 suffered the same fate with regular election (2005-2013) relating to the issue of financing the election. Many areas were almost delayed the implementation of the election, because it was unable to provide budget sourced from the budget which is relatively expensive. Hence, a simultaneous election system of 2015 has prompted by Minister of Home Affair on behalf of President shall perform the instructions on local governments to keep a fund for financing the general election.

Simultaneous election system of 2015 is different from the previous (2005-2013) in terms of organizing campaigns funded through local funds. In the conclave and 'face to face' meetings and dialogues financed candidates, while the public debate, dissemination of campaign materials, installation of props, the General Election Commision facilitated the mass media advertising through local funds. (Article 65 paragraph (2) Law Number 8 of 2015 on the Election of governors, regents and mayors).

A Model of the election campaign has thus been made which there is not vibrant and not lost interest, as a result, information about the General Election Commision and the track record of the candidates is not complete, tend to benefit incumbent and gave birth to a political culture of gambling in the General Election Commision concrurently this time. 
According to the article 12 PKPU Number 8 of 2015 on the General Election Campaign Fund, Participants have confirmed that a limit on campaign expenditures for gifts that can be incurred by a candidate is 25.000 (twenty five thousand rupiah). However, based on research results JPPR (People's Voter Educators Network) in 9 regions showed violations done by all candidates. Because the fact of campaign funds should not make a bundle (waste of money, for example, for shopping of household appliances, motorcycles, cars, even a pilgrimage to be given to voters. In fact, these expenditures are not included in the Statement of Revenue and Expenditure Campaign Fund (LPPDK). (Kompas, 2016: 2).

This means that simultaneous election system campaign funds allegedly used for political activities of money (money politics). However, the Election Supervisory Body (Bawaslu) does not have the authority to take action. Because the Law Number 8 of 2015 does not specifically regulate political action money, especially candidates who violate the provisions regarding the management of campaign funds. Consequently, Bawaslu used the provisions of Article 149 of Criminal Code, but was ineffective. Because the process is complicated and the proof is not simple.

Simultaneous election system of 2015 gave birth to a new tradition of democracy in the region because it can produce a number of female candidates in the election win this time. At least there are 35 women succeeded in making history as the head / deputy head of the region, equivalent to 13.25 percent of the total this election.

Simultaneous election system of 2015 was marred by the presence of a new tradition of the new party was able to win the hearts of voters. This is evidenced by the success of Nasdem Party was established in 2014, is capable of winning 129 Election or reap success reached 50.9 per cent (from 253 regions).

The Simultaneous election system of 2015 in this time also still marked by loneliness turnout to use their right to vote, which is only about 70 percent, even in some areas is very low turnout is below 60 percent, such as in Medan, North Sumatra. Only in some areas are high participation, in Depok and Surabaya.

A less participation does not affect the legal statutes election results. This Election remained 'valid de jure', but face constraints on populist legitimacy and ethics. This is due to publicly assume the general election only "game for the city" and is not related to any hope and vision for change in the real world. The critical point is beginning to look at the 2014 presidential election, voter turnout did not reach 70 percent. (Tengku Kemal Fasya, 2015: 6).

\section{Legal Policy Improvement of Simultaneous Election System}


At least there are some things that need to be improved in order to simultaneous election system in the future will be able to run democratically and able to contribute to the design of sustainable systems simultaneous election for investment growth of local democratization and to prepare the implementation of the concruent general election at a later stage the better.

\section{Simultaneous Election Financing of The Budget}

Simultaneous election matters of 2015 was quite captured by national attention and related to the issue of financing the general election. In a number of areas that have Budget (APBD) is small difficulties in financing election, hence some areas barely election held at a cost that is not sufficient and even trigger the central government (Ministry of Home Affairs) had to intervene and to lobby local governments to be more willing to fund simultaneous election of 2015. Areas that have a high budget election can be held costs fantastically even impressed wasteful. Therefore, the General Election in Indonesia has always been the same classical constraints, namely the matter of financing. Though Ministry of Home Affair and Ministry of Finance has been cooperating so that every area set aside budget each year to finance the simultaneous election of 2015, but in fact, they are insufficient budget funds. Moreover, financing of election in each area did not have the same relative standard financing.

this financing does not become a routine issue in the general election, it is necessary to prepare an alternative financing model is sourced from public funds in the form of the central government, the State Budget (APBN). Because the real-ageda development of local democratization agenda still require subsidies from public funds that are managed by the central government to regional public can have access to and participate in a powerful role in participating and control the projects of local democracy in a country. (Michael G. Miller, 2014: 12).

The need for financing through the state election are intended to synchronize the electoral system in Indonesia. Practically, there are three types of elections, the election of members of DPR, DPD and DPRD (legislatif election) and the election of president and vice president (Presidential Election) and at Local Elections. Indeed, the existence of each type of election is a unitary regime nationally. Even empirically all election organized by the same institution, namely the General Election Commission, Bawaslu and the Honorary Council Election (DKPP) is national, permanent, and independent as 
referred to in Article 22 of the Constitution 1945 which was later revealed in the Law Number 15 of 2011 on the Election.

Although the general election placed in the same regime, but in the context of financing are treated differently, legislative election and presidential election fund financed from the State Budget, Local Election financed from the local government budget. Supposedly these three types of elections was funded by the same funds. Although the general election held in the area, but in fact a strategic national agenda.

\section{Need for Preliminary Election}

The Revisions of Law Number 8 of 2015 on Election is necessary to accommodate the public test in the nomination process that can take place democratically. Public test of the prospective head region is required as a systematic attempt that the public can participate in the general election. During this stage of the nomination of the most crucial to realize a prospective regional heads capable in leading regions and has a track record of high moral integrity.

Experience shows simultaneous election of 2015, bring the nomination process is handed over to political parties tend to buy and sell tickets for the nomination. Political parties would only recommend and buy a ticket to the regional head candidates are popular and are willing to pour money dowry to the elite political parties, especially the Central Board (DPP) Political Parties as a single institution that can issue a recommendation candidacy.

The public test implementation of the pair of candidates is done by creating a model of the internal selection of political parties, starting from the village, district and county to prospective regent and deputy regent and district/municipality level for candidates for Governor and deputy governor in the form of elections intra political party or some sort of election preliminary (preliminary election) or Conventions. (Ramlan Surbakti, 2016: 4). This will systematically eliminate the practice of buying and selling tickets for the nomination and strengthen the basis of decentralization of political parties no longer rely on the recommendation of the elite political parties at the national level.

\section{Elimination of Threshold Conditions of Candidacy}

In the future, these matters should be considered to eliminate the threshold (candidacy requirements of threshold) requirements for the nomination. Due to the limitation threshold of seats of parliament and of the valid votes in legislative elections 
earlier. As a result, a number of areas in deficit prospective head region, even only by a single candidate.

On the other hand the need to update the model also prepared a new norm in Law Number 8 of 2015 on the General Election in order to create a formula of legal sanctions to political parties that do not submit a couple of candidates in the general election. Formula is a form of sanctions which allows the opportunity to close a political party to be able to participate in the nomination process at the next general election. Because if there is no sanctions would be open to 'elite' of the political parties to play a political party vehicle to reap economic benefits. Because of that Law Number 8 of 2015 on General Election need to be revised in order to punish the political parties did not exercise its right to propose a candidate pair.

In addition, the future needs of institutions prepared to increase the number of pairs of candidates in the general election, so that it will not happen any single candidate that may result in the absence of alternative candidates may be elected by the people. One of the important institutions that need to be prepared requisite support is ease of Identity Card (KTP) for candidates from individual lines (independent), because its weight in terms of support KTP Election Act has prompted individual candidates did not to register as prospective head region to the Genenal Election Commission.

The revised Law on election has been necessary to restore the requirement of support ID cards, such as Law Number 32 of 2004 on the Local Government which only requires 3.5 percent of support ID cards of the population, instead of 6.5-10 per cent as in Law Number 8 of 2015 on the Election governors, regents and mayors.

\section{Election Dispute to the Supreme Court}

Law Number 8 Year 2015 on the General Election need to be amended to restore the model dispute Resolution Election Results (RER) to the Supreme Court (MA). Primarily intended to follow up the Constitutional Court Decree Number 97 / PUU-XI / 2013, which declared the Constitutional Court is no longer authorized to hear disputes Election. In a verdict that the Constitutional Court wants to concern more on the implementation of the mandate of Article $24 \mathrm{C}$ of the 1945 Constitution and Law 23 of 2003 on the Constitutional Court which, among others, the Constitutional Court does not have the authority to direct the Election dispute resolution. Constitutional Court should be returned to the disposition of his birth, which is to preserve and uphold the 
constitution and the principles of law that can be testing and interpretation of the constitution. (Abdul Latif, 2009: 5-12).

Moreover, by removing the authority of the Court to resolve the RER returned to the Supreme Court, it is expected the Constitutional Court to maintain as the guardian of the constitution and to avoid collusive behavior, as was done by the former Chief Constitutional Court, Akil Mochtar, in dispute Local Election, (Kompas, 2013: 1).

Thus the Constitutional Court will be increasingly able to run its basic principles in the interpretation and testing of the constitution to be able to realize a democratic state. In this way the Constitutional Court will be able to make breakthroughs in the embodiment of the constitutional rights of every individual citizen in conducting judicial review of the issuance of a law that is detrimental to the individual, because it violates the constitution (Constitutional Questions). (Maruar Siahaan, 2009: 357-387 and I Dewa Gede Palguna, 2010: 1-20).

\section{Limitation on Lawsuit Administrative Court}

A revision of Law Number 8 of 2015 on the General Election is to create new models of norms and restrictions of time in law enforcement administration disputes Election process in the State Administrative Court (Administrative Court), this time limitation is very cudgel and done for administrative court rules, especially until the pending appeal in the Supreme Court will be able to disrupt the process and stages of election. Whereas the stages and election process can not stop or retreat to the back, because it will damage election system.

\section{Integrated Requirement of The Election Law Enforcement System}

In order to create a concruent election system democratic and avoid a criminal offense elections and electoral administration, systematic, massive and structured, it is necessary to reform the model of law enforcement administration, criminal law elections and the code of conduct elections within the law enforcement system electoral integrated and integrated. So do not give birth to a model settlement of electoral violations were not effective and brings a deterrent for the perpetrators and can reduce the degree of democracy.

At least there are two important things that need to be updated, first, integrating judicial election disputes in the roof (one roof system) under the coordination of the Election Supervisory Body (Bawaslu) to be able to finish in the final and binding on all 
kinds of violations of the election administration and criminal election. It's will speed up and streamline the course of the judicial process by setting a special election procedural law and its agents in particular. Second, Integrating all electoral ethics violations in one stop (one roof system) under the authority of the Honorary Board of Election (DKPP).

Hence, the authority of DKPP need to be expanded authority to enforce the code of conduct of all parties (actors) involved in both the electoral administration which is comprised of a board of political parties, election organizers (KPU and Bawaslu), participating in the election (candidates), voters, even the media. Even DKPP need to be given another authority to be able to assess whether the product bill on elections/election made by the House of Representatives who have been able to meet international electoral standards. DKPP within certain limits may give a recommendation to cancel the election law/election undemocratic.

\section{Closing}

\section{Conclusions}

a. The Simultaneous election systems of 2015 is a new system introduced by Law Number 8 of 2015 on Election of Governors, Regents and Mayors, but the selection policy of the law (legal policy) have simultaneous practiced in the form gradually, not at the same time in Indonesia, namely phase I (2015), phase II (2017), phase III and phase IV in 2018 to the 2021 that it will be held the national Election 2027. The meaning of simultaneous election law is, (a) for the efficiency and effectiveness of the Budget, with simultaneous models will be able to save costs to be issued in the General Election; (B) save time and energy providers; (C) eliminate boredom voters; (D) increase public control;; (F) presenting coattail effect, namely political action impacting to other measures (bandwagon effect).

b. Simultaneous election systems of 2015 first wave was held on December 9, 2015, with different dynamics. Simultaneous election is reviewed judicially againts the Constitution 1945. Constitutional Court is also the most widely issued a ruling that shocked and changed the political constellation law Election in Indonesia, ranging from relatives incumbent to become district head candidate (political dynasty), civil servants, military/polic/and Member of Parliament/DPRD should resign from office since becoming candidate, allowed suspects to be a candidate, remains despite the implementation of the general election that there is only one pair of candidates (single candidate), Constitutional 
Court to limit threshold dispute lawsuit Election Results between the winners and losers range of $0.5 \%-2 \%$.

c. The Implementation of the Simultaneous election systems of 2015 gave birth to a number of socio-political circumstances that require improvements in the future in order to create a fair system of election and democratic system, and sustainable system for Simultaneous election systems in next phase. Some things on the political aspects of the law need to be improved through amendment of Law Number 8 of 2015 is (a) needed diversion election financing of the budget so as not burden the state budget to local budgets; (B) the need to create a model for the Preliminary Election or Convention to be able to screen candidates and democratic regional head of quality; (C) restrictions on candidacy requirements (candidacy requirements of threshold) which shall not appear a single candidate and administrative sanctions on parties that did not nominate cadres; (D) the dispute settlement of election is returned to the Supreme Court; (E) the need to restrict a time of election administration disputes lawsuit in the Administrative Court; $(F)$ the need to build a model integration of election law enforcement system.

\section{BIBLIOGRAPHY}

Abdul Latif, 2009, Fungsi Mahkamah Konstitusi, Upaya Mewujudkan Negara Hukum Demokrasi, Total Media, Yogjakarta.

August Mellaz, 2007, "Efektifitas Pemerintahan dan Pelembagaan Sistem Kepartain Melalui Pelaksanaan Keserentakan Pemilu Nasional, dalam, http:// Augustmellar.multiply.journal.com/item/4, hal, 2. Diakses, 30 November 2011.

Budiman Tanuredjo, 2012, Pemilukada Langsung: Memutar Jarum Jam Sejarah Mungkinkah ? Sebuah Catatan, dalam Acmad Dodi Haryadi, 2012, Demokrasi Lokal Evaluasi Pemilukada Di Indonesia, Konprees, Jakarta.

Daimond, Larry, 2010, Indonesia's Place in Global Democracy, in Edward Aspinall and Marcuss Mietzner, 2010, Problems of Democratisation In Indonesia, Elections, Institutions and Society, ISEAS Singapore. 
Didik Supriyanto, 2012, Penataan Kembali Sistem Pemilihan dalam Pemilukada, dalam Achmad Dodi Haryadi, 2012, Demokrasi Lokal, Evaluasi Pemilukada di Indonesia, Konpress: Jakarta.

Djohermansyah Djohan, 2009, Penguatan Politik Lokal, dalam http://www.setneg.go.id/index.php?option=com_content\&task=view\&id=3519, diakses tanggal, 10 Februari 2016.

Djohermansyah Djohan, 2016, Merancang Pemilukada Yang Berkualitas, Kompas, 11 Februari 2016.

G. Miller, Micahael, 2014, Subsidizing Democracy, How Public Funding Changes Elections And How It Can Work In The Future, Cornel University Press, USA.

Golder, Matt, 2006, Presidential Coattails and Legislative Fragmentation, in American Journal Political Science, vol, 11 Januari 2006.

http://print.kompas.com/baca/2015/12/31/UU-Pemilukada -Paling-Banyak-Diuji-Materi, 31 Desember 2015, diakses tanggal 23 Februari 2016.

http://nasional.kompas.com/read/2015/02/17/15003821/RUU.Pemilukada .dan.Pemda.Disahkan.4.Fraksi.Setuju.Tanpa.Catatan, 17 Februari 2015, diakses tanggal 23 Februari 2016.

http://nasional.kompas.com/read/2013/10/03/0202549/Akil.Mochtar.Ditangkap.KPK.MK.Ak an.Bentuk.Majelis.Kehormatan, Diakses pada tanggal 21 Februari 2016.

I Gede Dewa Palguna, 2010, Constitutional Questions, Latar Belakang dan Pratek Di Negara Lain Serta Kemungkinan Penerapannya di Indonesia, dalam Jurnal Hukum Ius Qui Iustum, Number1 Vol. 17 Januari 2010, FH UII, Yogjakarta.

Mahfud MD, 2012, Evaluasi Pemilukada Perspektif Demokrasi dan Hukum, dalam Achmad Dodi Haryadi, 2012, Demokrasi Lokal, Evaluasi Pemilukada di Indonesia, Konpress: Jakarta.

Mahfud MD, 2010, Politik Hukum Di Indonesia, Rajawali Press, Jakarta.

Maruar Siahaan, 2009, Peran Mahkamah Konstitusi Dalam Penegakan Hukum Konstitusi, dalam Jurnal Hukum Ius Qui Iustum, Number3 Vol. 16 Juli 2009, FH UII, Yogjakarta.

Pemilukada Serentak, Dana Kampanye Rawan Manipulasi, Kompas, 13 September 2016.

Rawls, John, 1971, Theory of Justice, Harvard University Press, Cambridge.

Ramlan Surbakti, 2016, Pencalonan Tak Demokratis, Kompas, 18 Februari 2016. 
Samuels, Davids, 2000, Simultaneous Election, Discordant Result: Presidentialism, Federalism, and Governance in Brazil, International Journal of Comparative Politics, Volume 33, Nomor 1 Tahun 2000.

Siti Zuhro, 2015, Urgensi Pemilihan Kepala Daerah Serentak, dalam Saldi Isra, dkk, 2015 Pemilihan Umum Serentak, PT. Rajawali Press, Jakarta, hal, 367.

Teungku Kemal Fasya, 2015, Tingkat Kedemokratisan Pemilukada Kita, Kompas, 28 Desember 2015.

Wall, Alan, and Salih, Mohamed, 2007, Engineering Electoral Systems Possibilities and Pitfalls, NIMD Knowledge Centre, The Hague, The Netherlands. (@@@) 